\title{
Luteal function in sows after unilateral infusion of PGF-2a into the anterior uterine vein on different days of the oestrous cycle
}

\author{
T. Krzymowski, J. Kotwica, S. Okrasa, Teresa Doboszyńska* and \\ A. Zieçik
}

Institute of Animal Physiology and Biochemistry, and *Institute of Fundamental Veterinary Science, Academy of Agriculture and Technology, 10-718 Olsztyn, Poland

\begin{abstract}
Summary. Prostaglandin F-2 $\alpha(1.5 \mathrm{mg}$ over $10 \mathrm{~h})$ was infused into the anterior uterine vein of pigs on Days $6,8,10,12,14$ and 15 of the oestrous cycle. At each stage of the cycle PGF-2 $\alpha$ suppressed luteal function although the fall in progesterone secretion was much greater and statistically significant when the infusion was performed on Days 12, 14 and 15 of the cycle than on Days 6,8 and 10. The concentration of cAMP was depressed on Days 15 and 17 and fatty degeneration of luteal cells on Days 6-8 or 14 was more pronounced in the ovary ipsilateral to the PGF- $2 \alpha$ infusion than in the contralateral ovary. The results are compatible with the local perfusion of PGF- $2 \alpha$ from the anterior uterine vein to the ipsilateral ovary, but a systemic effect was also apparent.
\end{abstract}

\section{Introduction}

Prostaglandin (PG) F-2 $\alpha$ is known to be luteolytic in many species of domestic animals (Pharriss, Tillson \& Erickson, 1972) but there is evidence from several investigations that the corpus luteum of the pig is resistant to exogenous PGF-2 $\alpha$ for the first 10-12 days of the cycle (Diehl \& Day, 1974; Hallford, Wettemann, Turman \& Omtvedt, 1975; Moeljono, Bazer \& Thatcher, 1976; Connor, Phillips \& Palmer, 1976). The mechanism whereby PGF-2 $\alpha$ reaches the ovary from the uterus is not yet known. In the ewe PGF- $2 \alpha$ is believed to pass from the uterine vein to the associated ovarian artery and hence to the ovary (Barrett et al., 1971; Goding, Baird, Cumming \& McCracken, 1972; McCracken et al., 1972). The experimental results of Caldwell \& Moor (1971), Ginther \& Bisgard (1972), Goding (1974) and Land, Baird \& Scaramuzzi (1976) have supported this suggestion, although Coudert, Phillips, Faiman, Chernecki \& Palmer (1974) and Shemesh \& Hansel (1975) were unable to obtain confirmatory evidence. As far as we know there is no information on the mechanism of prostaglandin transfer in the pig. The papers of Gleeson (1974) and Lindloff, Holtz, Elsaesser, Kreikenbaum \& Smidt (1976) give only limited details. The present study was therefore an investigation of the influence of PGF-2 $\alpha$ on corpora lutea of the pig when infused into the anterior uterine vein at various stages of the cycle.

\section{Materials and Methods}

The experiments were carried out with pigs of the Polish Large White breed weighing about $150 \mathrm{~kg}$ after the 1st or 2nd farrow. The first day of oestrus was designated Day 0 of the oestrous cycle. Anaesthesia was induced by intravenous administration of sodium pentobarbitone (Nembutal) in a dose of $0.2 \mathrm{ml} / \mathrm{kg}$ body weight, and was further maintained with a mixture of ether and oxygen in a closed circuit. One cannula was inserted through the vena cephalica humeri into the external jugular vein and exteriorized by passage under the skin to the back for withdrawal of blood samples. The second cannula was inserted through a small branch of the anterior uterine vein, in that part of the right horn adjacent to the ovary, into the anterior uterine vein up to a distance of about $5 \mathrm{~cm}$ before 
the junction of the anterior uterine and ovarian veins, i.e. anterior to the site where the ovarian artery forms a loop over the ovarian vein. The peripheral end of the cannula was led through the abdominal wall under the skin to the animal's back and was used for the infusion of PGF- $2 \alpha$ or saline. On the 3rd day after operation each sow was given a 10-h infusion of Prostin (Upjohn Co., Kalamazoo, U.S.A.) containing $1.5 \mathrm{mg}$ PGF- $2 \alpha$ dissolved in $200 \mathrm{ml}$ sterile physiological saline (0.154 $\mathrm{M}-\mathrm{NaCl})$. The control pigs received a $10-\mathrm{h}$ infusion of $200 \mathrm{ml}$ saline. PGF-2 $\alpha$ infusions were performed on Days $6,8,10,12,14$ or 15 of the oestrous cycle and saline infusions on Days 6 or 14. Ovariectomy was performed on the 15th day of the cycle, except for the animals infused on the Days 14 and 15 which were ovariectomized on Days 17 and 18 respectively. The excised ovaries were placed on ice and the corpora lutea (CL) were at once dissected out. One part of each $\mathrm{CL}$ was frozen in liquid nitrogen for later determination of cyclic AMP, and another part, for histological examination, was fixed in AFA solution ( $96 \%$ ethanol-formalin-glacial acetic acid; $90: 5: 5$ by vol.), embedded in paraffin wax, sectioned and stained with Delafield's haematoxylin and eosin or with Mallory's trichrome stain. A third part of each CL was fixed in $10 \%$ neutral formalin, sectioned with a freezing microtome and stained with Sudan III.

Measurement of cyclic AMP. This was determined by the method of Brown, Albano, Ekins \& Segherzi (1971) for $4 \mathrm{CL}$ from each ovary of each sow. The cAMP binding protein was isolated from bovine adrenals and used at $1: 20$ dilution. The frozen $C L$ were comminuted and treated with $0.5 \mathrm{ml}$ cold $1.5 \mathrm{M}$-perchloric acid/g tissue in a mortar cooled with liquid nitrogen. After partial digestion, $1 \mathrm{ml}$ EDTA was added. The extract was centrifuged at $3000 \mathrm{~g}$ for $20 \mathrm{~min}$ at $0^{\circ} \mathrm{C}$ and the supernatant was adjusted to $\mathrm{pH} 7$ with $\mathrm{KOH}$. The interfering nucleotides were precipitated with zinc sulphate and barium hydroxide (Goff \& Major, 1975). The cAMP was a Calbiochem product and the tritiated cAMP (sp.act. $27 \mathrm{Ci} / \mathrm{mmol}$ ) was received from the Radiochemical Centre, Amersham, England. The sensitivity of the assay, i.e. the lowest amount of cAMP which could be measured, was $0.2 \mathrm{pmol}$ per incubation test tube $(4 \mathrm{pmol} / \mathrm{ml})$. The within-assay variation for tests in duplicate was $3.4 \%$.

Progesterone. The progesterone level in the peripheral plasma was determined by a modification of the competitive protein-binding technique of Johansson (1970). The modification of the method consisted in the use of cortisol for preparation of the test system and the use as binding protein of plasma from a 1-year-old dog previously injected intramuscularly with dexamethasone. The sensitivity of determinations, i.e. the lowest amount differing significantly from zero, was $0.05 \mathrm{ng} / \mathrm{sample}$ or $0.75 \mathrm{ng} / \mathrm{ml}$ plasma. A linear regression equation $(y=-0.025+1.084 x)$ was calculated from the determinations of known amounts of progesterone ( $1 \mathrm{ng}, n=5 ; 5 \mathrm{ng}, n=4 ; 10 \mathrm{ng}, n=5 ; 20 \mathrm{ng}, n=5$ ) added to the plasma of a bilaterally ovariectomized and hysterectomized sow. The intra-assay and inter-assay variations were, respectively, $6.5 \%$ (for 11 determinations in duplicate) and $17.09 \%$ (for 15 determinations in duplicate).

All radioactivity measurements were performed with a liquid scintillation Spectrometer SL 40 (Intertechnique).

Statistical significance of differences between mean values was assessed by Student's $t$ test.

\section{Results}

\section{Progesterone values}

Table 1 shows the peripheral plasma progesterone levels obtained during the infusions. The effects on plasma levels on various days after infusion are shown in Text-fig. 1. The level of progesterone fell most steeply after infusion on the 12th, 14th and 15th days of the cycle. After infusion on Day 10, the progesterone levels had dropped only by the 5 th day. The results obtained in the group receiving PGF-2 $\alpha$ infusions on the 6th day of the cycle were compared with the progesterone levels in a pig given the saline infusion on Day 6 of the cycle. In this sow the initial progesterone level on Day 6 was $11 \cdot 02 \mathrm{ng} / \mathrm{ml}$ and on successive days it was $13 \cdot 65,14 \cdot 82,15 \cdot 63,15 \cdot 71,15 \cdot 33,17 \cdot 69,20 \cdot 21$, 14.82 and $6.92 \mathrm{ng} / \mathrm{ml}$, indicating that the peak level was on 13 th day of the cycle. Similar patterns and values have been found for sows in which progesterone levels were determined under normal conditions (Okrasa, 1978). These results therefore show that after infusion of PGF-2 $\alpha$ on the 6th day of 


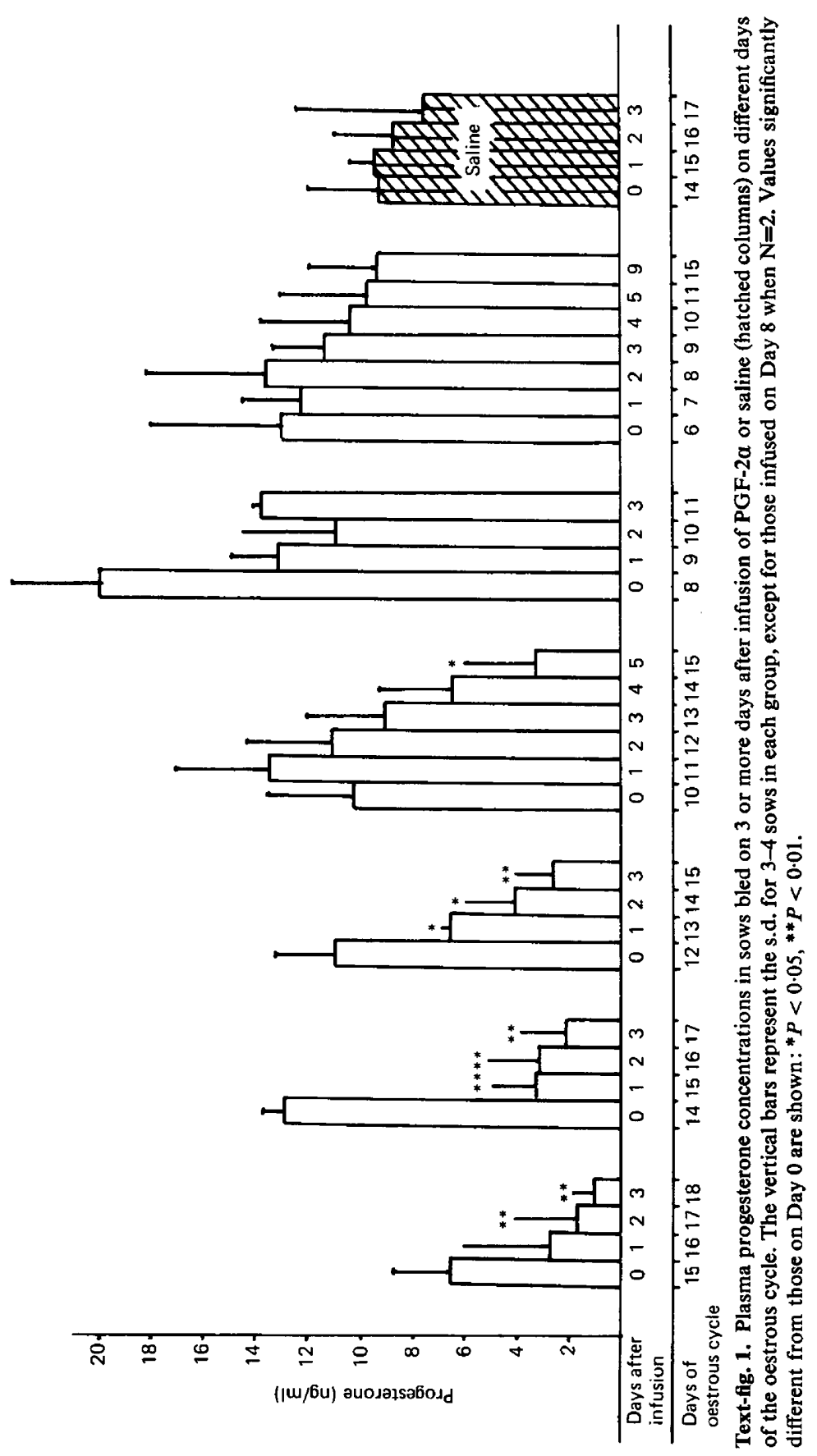


the cycle there was no significant fall of progesterone level but that the physiological rise which is characteristic for this period of CL development failed to appear. The sensitivities of the CL to PGF-2 $\alpha$ in relation to the day of the cycle on which the infusion was performed are demonstrated in Text-fig. 2.

Table 1. Progesterone plasma concentrations (mean \pm s.d.) in pigs during a 10-h infusion of PFG-2 $\alpha$ or saline on different days of the oestrous cycle

\begin{tabular}{|c|c|c|c|c|c|c|c|c|}
\hline \multicolumn{2}{|c|}{ Infusion } & \multirow{2}{*}{$\begin{array}{l}\text { No. of } \\
\text { sows }\end{array}$} & \multicolumn{6}{|c|}{ Duration of infusion (h) } \\
\hline Substance & Day & & 0 & 2 & 4 & 6 & 8 & 10 \\
\hline Saline & $\begin{array}{r}6 \\
14\end{array}$ & $\begin{array}{l}1 \\
3\end{array}$ & $\begin{array}{r}11.02 \\
9.17 \\
+1.80\end{array}$ & $\begin{array}{r}11.08 \\
8.41 \\
+1.57\end{array}$ & $\begin{array}{r}10.76 \\
9.93 \\
+0.60\end{array}$ & $\begin{array}{r}11.56 \\
9.28 \\
\pm 4.09\end{array}$ & $\begin{array}{r}9.93 \\
9.01 \\
+3.58\end{array}$ & $\begin{array}{r}8.06 \\
7.75 \\
\pm 2.18\end{array}$ \\
\hline PGF-2 $\alpha$ & $\begin{array}{l}10 \\
12\end{array}$ & 2 & $\begin{array}{r}13.04 \\
\pm 4.98 \\
19.97 \\
\pm 3.28 \\
10.18 \\
\pm 3.41 \\
10.90 \\
\pm 2.31 \\
12.88 \\
\pm 0.80 \\
6.54 \\
\pm 2.12\end{array}$ & $\begin{array}{r}12.07 \\
\pm 5.88 \\
22.64 \\
\pm 1.12 \\
9.13 \\
+5.49 \\
7.29 \\
\pm 0.22 \\
10.73 \\
\pm 4.58 \\
4.83 \\
\pm 1.44\end{array}$ & $\begin{array}{r}11.39 \\
\pm 6.26 \\
18.98 \\
\pm 0.48 \\
9.73 \\
\pm 6.76 \\
7.58 \\
\pm 2.50 \\
9.37 \\
\pm 1.42^{* *} \\
3.71 \\
\pm 0.25^{*}\end{array}$ & $\begin{array}{c}11.38 \\
\pm 3.29 \\
17.53 \\
\pm 0.24 \\
8.66 \\
\pm 2.83 \\
5.75 \\
\pm 0.28^{*} \\
9.44 \\
\pm 0.68^{* *} \\
3.56 \\
\pm 1.00^{*}\end{array}$ & $\begin{array}{r}13.09 \\
\pm 5.10 \\
15.32 \\
\pm 3.05 \\
7.47 \\
\pm 2.64 \\
6.31 \\
\pm 0.60^{*} \\
8.52 \\
\pm 5.19 \\
3.71 \\
\pm 1.23\end{array}$ & $\begin{array}{c}11 \cdot 31 \\
\pm 5 \cdot 14 \\
12 \cdot 72 \\
\pm 2 \cdot 62 \\
8.74 \\
\pm 3.08 \\
7.30 \\
\pm 3.34 \\
7 \cdot 00 \\
\pm 2 \cdot 80^{* *} \\
2.90 \\
\pm 1.49^{*}\end{array}$ \\
\hline
\end{tabular}

Values significantly different when compared to that at $0 \mathrm{~h}$ of infusion: ${ }^{*} P<0.05 ;{ }^{* *} P<0.01$.

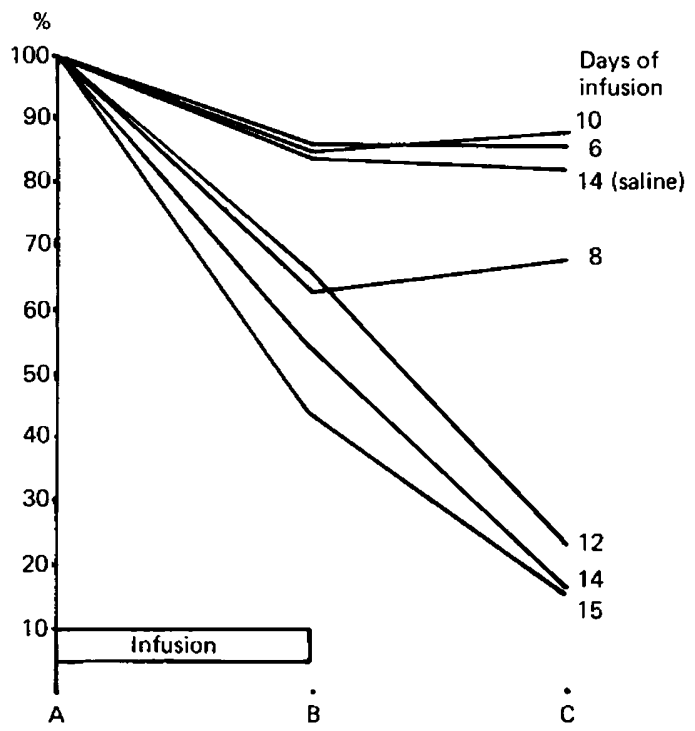

Text-fig. 2. Percentage changes in the plasma progesterone levels of sows after PGF-2 $\alpha$ or saline infusion on different days of the oestrous cycle. $\mathrm{A}=$ the plasma progesterone concentration $(100 \%)$ on the day of infusion; $B=$ end of the 10 -h infusion; $C=3$ days after the infusion. 

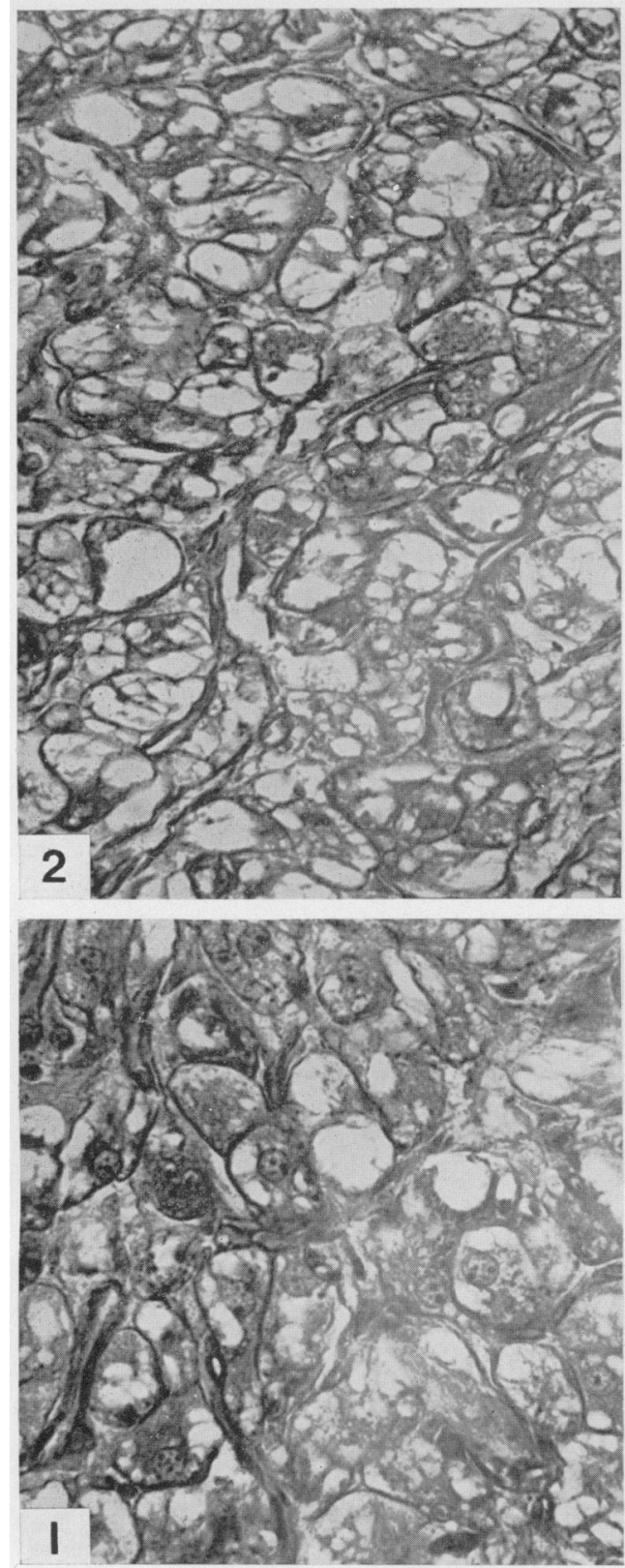
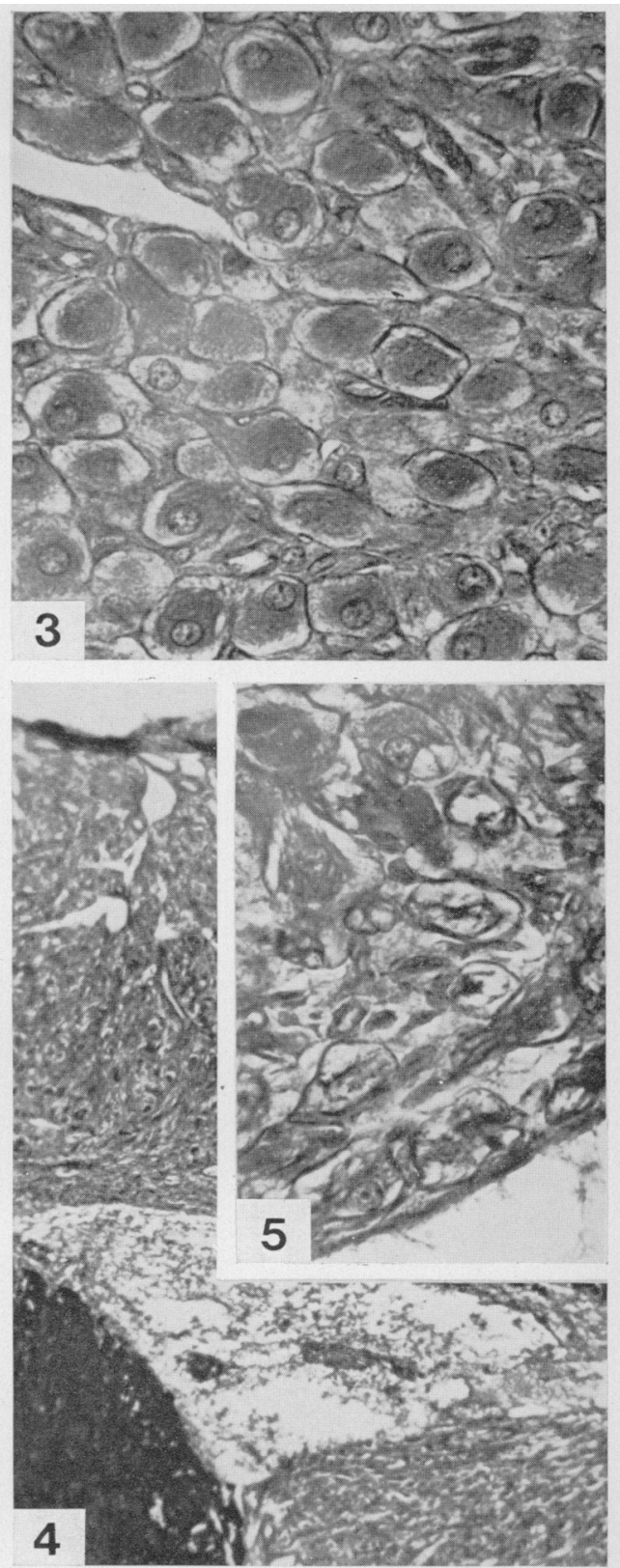

Fig. 1. Luteal tissue from the left ovary of a sow infused with PGF-20 on Das 12 and owariectomized on Day 15 of the oestrous excle. Mallory, $\times 500$.

Fig. 2. Luteal fisste from the righe wary of a sow infused with PCiF-2u on Das 12 and orariectomized on Day 15 of the oestrous elele. howing more extenside fatly degeneration than in the leti ovary (Fig. 1). Mallor: $\times 500$.

Fig. 3. A controf corpus lateum from the right ovars of a sow infused with saline on Dat 14 and ovarjectomied on Da! 17 of the oestrous crele. Mallor! $x 500$.

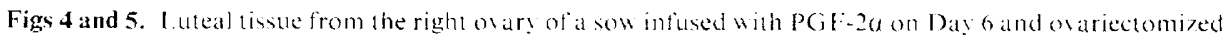
on Das 15 of the oestrous cucke showing the failure of the Cl. we develop normally (1-ig. $4: \times 50)$ and the early fall degeneration trig. $5: x, 50)$. 


\section{Histology}

The $\mathrm{CL}$ in the right and left ovaries of the pigs receiving saline infusions appeared similar and there was little evidence of fatty degeneration (PI. 1, Fig. 3). However, in all the sows receiving the PGF-2 $\alpha$ infusion (into the right uterine vein) there was much greater fatty degeneration in the CL of the right (Pl. 1, Fig. 2) than the left (Pl. 1, Fig. 1) ovary, regardless of the day on which PGF-2 $\alpha$ was infused and the interval between infusion and ovariectomy. The fatty degeneration in the left $C L$ of the PGF-2 $\alpha$-infused animals (PI. 1, Fig. 1) was greater than that in the CL of control animals (Pl. 1, Fig. 3), although the latter were older. Fatty degeneration of the luteal cells was present in the CL of pigs infused with PGF-2 $\alpha$ on Day 6 and ovariectomized on Day 15 (PI. 1, Figs 4 and 5).

Similar results were obtained with all three stains used.

\section{Cyclic AMP concentrations}

These were measured to try and determine the mechanism whereby PGF- $2 \alpha$ acts. As shown in Table 2, there were no differences in cAMP concentration in right and left CL from saline-infused animals, but infusion of PGF- $2 \alpha$ caused a reduction in luteal cAMP levels which was more pronounced in right than in left ovaries.

Table 2. The cAMP level (mean \pm s.d.) on Days 15 or 17 of the oestrous cycle in pig corpora lutea of the left and right ovary after infusion of PGF-2 $\alpha$ into the anterior uterine vein on the right side of the uterus on different days of the cycle

\begin{tabular}{|c|c|c|c|c|c|}
\hline \multicolumn{2}{|c|}{ Day of cycle for: } & \multirow[b]{2}{*}{$\begin{array}{l}\text { No. of } \\
\text { sows }\end{array}$} & \multirow[b]{2}{*}{$\begin{array}{l}\text { No. of } \\
\text { CL }\end{array}$} & \multicolumn{2}{|c|}{ cAMP concentration (nmol/g CL) } \\
\hline Infusion & $\begin{array}{c}\text { cAMP } \\
\text { measurement }\end{array}$ & & & Left ovary & Right ovary \\
\hline 14 (saline) & 17 & 3 & 24 & $0.575 \pm 0.068$ & $0.567 \pm 0.098$ \\
\hline 14 (PGF-2 $\alpha$ ) & 17 & 3 & 24 & $0.533 \pm 0.189^{*}$ & $0.388 \pm 0.098 \dagger$ \\
\hline 12 (PGF-2a) & 15 & 4 & 32 & $0.502 \pm 0.210$ & $0.417 \pm 0.120$ \\
\hline $10(\mathrm{PGF}-2 \alpha)$ & 15 & 4 & 32 & $0.397 \pm 0.024$ & $0.422 \pm 0.094$ \\
\hline 6-8 (PGF-2 $\alpha)$ & 15 & 4 & 32 & $0.517 \pm 0.041^{*}$ & $0.290 \pm 0.062$ \\
\hline
\end{tabular}

* Significantly different from corresponding value in right ovary, $P<0.01$.

$\dagger$ Significantly different from value for right ovary of saline-infused animals, $P<0 \cdot 01$.

\section{Discussion}

The purpose of the work was to find the answer to two questions: (1) has prostaglandin a luteolytic effect on the pig CL in vivo before Day 12 of the oestrous cycle, and (2) does prostaglandin infusion into the anterior uterine vein of only one uterine horn result in similar structural and functional changes in both ovaries?

The results showed that pig CL responded to exogenous PGF-2 $\alpha$ infused into the uterine veins in vivo on Days $6,8,10,12,14$ and 15 of the oestrous cycle. The response did, however, differ according to the developmental stage of the CL: all CL were histologically affected by the PGF- $2 \alpha$ but progesterone levels were not always decreased, e.g. after infusion on Day 6. Although PGF-2 $\alpha$ administration on Day 6 failed to induce full luteolysis and a significant fall of progesterone level, it did inhibit normal CL growth and prevent the rise in plasma progesterone which is characteristic for the normal oestrous cycle. Our results differ from those reported by Diehl \& Day (1974), Hallford et al. (1975) and Moeljono et al. (1976), all of whom used a high (5-80 mg) intramuscular dose of PGF-2 $\alpha$ and failed to demonstrate an effect of PGF-2 $\alpha$ before the 12th day of the oestrous cycle. On the other hand, our observations confirm, in part, and extend the results obtained by Connor et al. (1976) who demonstrated sensitivity of pig CL to PGF-2 $\alpha$ on Days 9 and 10 of the cycle, and the results of 
Guthrie \& Polge (1976) who used a prostaglandin analogue(ICI 79,939) and demonstrated a significant fall of plasma progesterone level on the 8 th, 9 th, 10 th and 12th days of the cycle. The doses we used $(10 \mu \mathrm{g} / \mathrm{kg}$, i.e. $1.5 \mathrm{mg}$ PGF- $2 \alpha / \mathrm{pig})$ were much lower than those used by other authors and the route of administration was more direct. Gleeson (1974) infused $3 \mathrm{mg} \mathrm{PGF}-2 \alpha$ at a rate of $125 \mu \mathrm{g} / \mathrm{h}$ during $24 \mathrm{~h}$ into the ovario-uterine vein of unilaterally ovariectomized pigs and observed a rise of progesterone from 10 to $26 \mathrm{ng} / \mathrm{ml}$ followed by a fall to $2 \mathrm{ng} / \mathrm{ml}$ which persisted for 3 days. We also observed a fall of progesterone level (statistically significant) after PGF-2 $\alpha$ infusion but it was not as great as that reported by Gleeson (1974) or by Moeljono et al. (1976) and Hallford et al. (1975) who obtained reductions from 10 to $<1 \mathrm{ng} / \mathrm{ml}$ and 36 to $3 \mathrm{ng} / \mathrm{ml}$ respectively. Apart from the different doses used, the less pronounced fall observed by us may have been due to the presence of the contralateral ovary in which the CL were less affected (Table 1 ; Pl. 1 ; Figs 1 and 2).

The effectiveness of the small dose of PG administered via the anterior uterine vein, the lack of effect of much higher doses administered intramuscularly by other authors, and the greater luteolytic changes in the ipsilateral ovary than in the contralateral ovary suggest that PGF- $2 \alpha$ exerts a local effect without mediation of the hypothalamo-hypophysial axis. A local effect is also indicated by the results obtained by Hallford et al. (1975), Connor et al. (1975) and Lindloff et al. (1976) who reported reduced progesterone levels after PGF- $2 \alpha$ administration although LH concentrations rose only after several days. Our present studies do not clarify how the PGF-2 $\alpha$ acts: the prompt response of the CL to small doses of PGF-2 $\alpha$ infused into the uterine vein suggests a local effect as in sheep (see Land et al., 1976) but the luteolytic action on the contralateral ovary, albeit reduced, also indicates a systemic effect.

In the experiments so far reported, measurements of progesterone production have been the main criterion of functional activity of the $\mathrm{CL}$, but in the present investigations CAMP concentrations were also determined because Ahrén et al. (1974) observed a rise in cAMP level during CL development and a significant fall during CL regression in rats. The present experiments also considered the morphology of the CL and the differences between CAMP levels were compared between the CL of the left and right ovaries in the same group or between $C L$ in experimental and control pigs which were ovariectomized on the same day after infusion. The correlation found between the lowered cAMP level and increased fatty degeneration of luteal cells after PGF- $2 \alpha$ administration supports the hypothesis of Henderson \& McNatty (1976) that PG exerts its effect at the level of the corpus luteum and acts particularly on the adenylate cyclase which determines the synthesis of cAMP. When cAMP is absent, phosphatase converts cholesteryl esterase to its inactive form and this leads to a fall in progesterone production.

We thank Dr J. W. Lauderdale (Upjohn Co., Kalamazoo) for the prostaglandin. This work was supported by the Institute of Pathology and Therapy of Animals, Agriculture Academy, Wroclaw, as part of the Research Project of the Ministry of Higher Education, Science and Technology (MR-II-10).C. Nagięc took the photographs.

\section{References}

Ahrén, K., Herlitz, H., Nilsson, L,, Perklev, T., Rosberg, S. \& Selstam, G. (1974) Gonadotropins and cyclic AMP in various compartments of the rat ovary. In Gonadotropins and Gonadal Function, pp. 364-375. Ed. N. R. Moudgal. Academic Press, New York.

Barrett, S., Blockey, M.A. de B., Brown, J.M., Cumming, S.A., Goding, J.R., Mole, B.J. \& Obst, J.M. (1971) Initiation of the oestrous cycle in the ewe by infusions of PGF-2 $\alpha$ into the autotransplated ovary. J. Reprod. Fert. 24, 136-137.
Brown, B.L., Albano, J.D.M., Ekins, R.P. \& SegHERZI, A.M. (1971) A simple and sensitive saturation assay method for the measurement of adenosine $3^{\prime}, 5^{\prime}$ cyclic monophosphate. Biochem. J. 121, $561-562$.

Caldwell, B.V. \& Moor, R.M. (1971) Further studies on the role of the uterus in the regulation of corpus luteum function in sheep. $J$. Reprod. Fert. 26, 133139.

Coudert, S.P., Phillips, G.D., Faiman, C., CherNECKI, W. \& PALMER, M. (1974) Infusion of tritiated 
prostaglandin $\mathrm{F}_{2 a}$ into the anterior uterine vein of the ewe: absence of local venous-arterial transfer. J. Reprod. Fert. 36, 333-343.

Connor, L., Phil.lips, G.D. \& Palmer, W.M. (1976) Effects of prostaglandin $F_{2 \alpha}$ on the oestrous cycle and hormone levels in the gilt. Can. J. Anim. Sci. 56, 661-669.

DIEHL, J.R. \& DAY, B.N. (1974) Effect of prostaglandin $\mathrm{F}_{2 \alpha}$ on luteal function in swine. J. Anim. Sci. 39, 392-396.

GinTher, O.J. \& Bisgard, G.E. (1972) Role of main uterine vein in local action of an intrauterine device on the corpus luteum in sheep. Am. J. vet. Res. 33, 1583 1590 .

GleEsoN, A.R. (1974) Luteal function in the cyclic sows after infusion of prostaglandin $F_{2 \alpha}$ through a uterine vein. J. Reprod. Fert. 36, 487-488.

Goding, J.R. (1974) The demonstration that PGF $F_{2 \alpha}$ is the uterine luteolysin in the ewe. J. Reprod. Fert. 38, 261-271.

Goding, J.R., Baird, D.T., Cumming, S.A. \& MCCraCKEN, J.A. (1972) The functional assessment of autotransplanted endocrine glands. Acta endocr., Copenh., Suppl. 158, 169-199.

GoFF, A.K. \& MAJOR, P.W. (1975) Concentration of cyclic AMP in rabbit ovarian tissue during the preovulatory period and pseudopregnancy after induction of ovulation by administration of human chorionic gonadotrophin. J. Endocr. 65, 73-85.

GuThrie, H.D. \& Polge, C. (1976) Luteal function and oestrus in gilts treated with a synthetic analogue of prostaglandin $F_{2 \alpha}$ (ICI 79,939) at various times during the oestrous cycle. J. Reprod. Fert. 48, 423-425.

Hallford, D.M., WettemanN, R.P., TuRman, E.J. \&
OMTVEDT, J.T. (1975) Luteal function in gilts after prostaglandin $\mathrm{F}_{2 \alpha}$.J. Anim. Sci. 41, 1706-1710.

Henderson, K.M. \& McNatTy, K.P. (1975) A biochemical hypothesis to explain the mechanism of luteal regression. Prostaglandins 9, 779-797.

JohansSON, E.D.B. (1970) A simplified procedure for the assay of progesterone. Acta endocr., Copenh., Suppl. 147, 188-203.

LAND, R.B., BaIRD, D.T. \& ScaramuzzI, R.J. (1976) Dynamic studies of prostaglandin $F-2 \alpha$ in the utero-ovarian circulation of the sheep. $J$. Reprod. Fert. 47, 209-214.

Lindloff, G., Holtz, W., Elsaesser, F., Kreikenbaum, K. \& SMIDT, D. (1976) The effect of prostaglandin $F_{2 x}$ on corpus luteum function in the Götingen Miniature Pig. Biol. Reprod. 15, 303-310.

McCracken, J.A., Carlson, J.C., Glew, M.E., Goding, J.R., Baird, D.T., Green, K. \& SamuelssON, B. (1972) Prostaglandin $F_{2 \alpha}$ identified as a luteolytic hormone in sheep. Nature, New Biol. 238, 129-134.

Moeljono, M.P.E., Bazer, F.W. \& Thatcher, W.W. (1976) A study of prostaglandin $F_{2 x}$ as the luteolysin in swine. I. Effect of prostaglandin $F_{2 \alpha}$ in hysterectomized gilts. Prostaglandins 11, 737-743.

OkrasA, S. (1978) Changes in progesterone level in the plasma of sows during the estrous cycle. Acta physiol. pol. 29, 177-183.

Pharriss, B.B., Tillson, S.A. \& Erickson, R.R. (1972) Prostaglandins in luteal function. Recent Prog. Horm. Res. 28, 51-89.

Shemesh, M. \& Hansel, W. (1975) Levels of prostaglandin $F$ (PGF) in bovine endometrium, uterine venous, ovarian arterial and jugular plasma during the estrous cycle (38489). Proc. Soc. exp. Biol. Med. 148, 123-126.

Received 23 August 1977 